(c) The Author(s), 2021. Published by Cambridge University Press. This is an Open Access article, distributed under the terms of the Creative Commons Attribution licence (https://creativecommons.org/licenses/by/4.0/), which permits unrestricted re-use, distribution, and reproduction in any medium, provided the original work is properly cited. doi:10.1017/S1474746421000683

\title{
Extra Care Housing: The Current State of Research and Prospects for the Future
}

\author{
Robin A. Darton
}

Personal Social Services Research Unit, University of Kent, Canterbury, UK Email: R.A.Darton@kent.ac.uk

Extra care housing aims to meet the housing, care and support needs of older people, while maintaining their independence in self-contained accommodation. Evidence from several studies suggests that it has benefits for residents in terms of costs and outcomes, and can provide a supportive environment for people with dementia, although the benefits for residents with greater care needs are less clear. Budgetary pressures and increasing eligibility criteria are altering the balance of care between residents and resulting in more task-focused, less personalised care. An increasing shortfall in provision and incentives for developers to concentrate on 'lifestyle' provision raise questions about the long-term viability of the model for supporting local authority-funded residents. Responses to the coronavirus pandemic also raise questions about future housing and care arrangements, and these need to be addressed in the government's long-delayed plans for social care.

Keywords: Dementia, extra care housing, older people, social care.

\section{Introduction}

A long-standing principle underlying government policy in the United Kingdom, and internationally, has been to help people maintain their independence in their own homes for as long as possible, termed 'ageing in place' (Department of Health and Social Security, Scottish Office, Welsh Office and Northern Ireland Office, 1981; Department for Communities and Local Government, Department of Health and Department for Work and Pensions, 2008; World Health Organization, 2015; Department for Communities and Local Government, 2017b). Measures to improve and adapt ordinary housing and to enable downsizing to smaller, more manageable accommodation help older people remain in their own homes (Department of Health and Department of the Environment, 1997; Department for Communities and Local Government, Department of Health and Department for Work and Pensions, 2008; Department for Communities and Local Government, 2017b). However, more specialist forms of integrated housing with care have been developed where adequate care and support cannot be provided in mainstream housing. Extra care housing aims to meet housing, care and support needs, while helping older people maintain their independence in their own private accommodation.

In 2011, 96 per cent of people aged 65 and over in England and Wales were living in households and only 3.7 per cent were living in communal establishments, mainly care homes (Office for National Statistics, 2013, 2015). In 2014, around 5 per cent of households in England occupied sheltered housing, defined as accommodation with a 
warden or manager (Department for Communities and Local Government, 2016, Annex Table 2.6). The 2008 national housing strategy (Department for Communities and Local Government, Department of Health and Department for Work and Pensions, 2008) indicated that population ageing required a strategic approach: the number of people aged 85 or over was projected to increase by 184 per cent by 2036 and the number aged 65 or over with dementia was projected to increase by 154 per cent by 2051 .

Over the last 50 years the physical standard of housing has improved significantly (Department for Communities and Local Government, 2017a), but housing problems disproportionately affect older households. In 2019, 17 per cent of homes in England failed to meet the Decent Homes Standard (Ministry of Housing, Communities and Local Government, 2020) and, in 2018, only 9 per cent had four key accessibility features (Ministry of Housing, Communities and Local Government, undated). People aged 85 or over are most likely to live in non-decent homes, and households with people aged 85 or over are most likely to include someone with a long-term illness or disability (Department for Communities and Local Government, 2016).

\section{Aims and methodology}

This article draws on policy and research literature, including several reviews (Darton and Muncer, 2005; Croucher et al., 2006; Evans, 2009a; Atkinson et al., 2014) and the annual UK Market Report by LaingBuisson (2016), to examine the development of, and issues relating to, the provision of extra care housing. In particular, the article discusses the support of frail residents, including the impact of the coronavirus (COVID-19) pandemic.

Key findings are presented from a number of studies, including: an evaluation of 19 schemes supported by the Extra Care Housing Fund by the PSSRU (Netten et al., 2011); the ASSET study, conducted in nine schemes in five local authorities in 2012-2014 (NIHR School for Social Care Research, undated); and the ECHO study, conducted in four schemes in two local authorities in 2015-2017 (NIHR School for Social Care Research, 2018). The relevant ethical approvals for these studies are reported in Darton et al. (2012), Evans et al. (2017) and Cameron et al. (2019).

Extra care housing is available in the constituent countries of the UK (Housing Learning and Improvement Network, 2017), but separate legislation applies in each country and most of the research studies examined were undertaken in England.

\section{The development and role of extra care housing in the UK}

Sheltered housing for older people was developed by local authorities following the Second World War to provide specialised accommodation for rent while housing reconstruction focused on family housing. A variety of models have been created, and there has been confusion about definitions (Darton and Muncer, 2005). However, the principal features of sheltered housing are a resident or on-call warden or scheme manager, an alarm system and some communal facilities (Butler et al., 1983; LaingBuisson, 2016). Housing associations now manage most sheltered housing (LaingBuisson, 2016). A growing need for care and support in sheltered housing, the unpopularity of some schemes, poor quality local authority residential accommodation and developments enabling people to age in place led to increasing interest in very sheltered housing (Fletcher et al., 1999). This offered enhanced design features, full-time warden cover and 
domiciliary services, and aimed to provide an alternative to residential care (Reed et al., 1980; Butler et al., 1983).

Atkinson et al. (2014) identified a wide range of types of provision and terminology, across various countries, reinforcing the findings of Howe et al. (2013), who identified over 90 terms used in the UK, the USA, Canada, Australia and New Zealand for housing with support and care services. In the UK, 'extra care housing' has become the most widely used term, largely replacing 'very sheltered housing', although some private providers prefer 'assisted living' (LaingBuisson, 2016). In the USA, assisted living is similar to residential care (LaingBuisson, 2016). 'Extra care housing' is the term used here, except when referring to original material.

Extra care housing can take a variety of forms, but the principal features include selfcontained living accommodation, the availability of 24-hour care and access to communal facilities and services (LaingBuisson, 2016). The majority of schemes are free-standing developments, typically with 40 or more units of accommodation. Larger retirement villages, typically with 100 or more units (Evans, 2009a), offer more social and leisure 'lifestyle' activities and more accommodation for purchase. However, they offer care and support where required, and some are specifically designed as extra care villages.

At an operational level, local authorities commission extra care housing by negotiating nomination agreements with providers, specifying eligibility criteria. A national minimum threshold for eligibility for services is set out in regulations under the Care Act 2014, but local authorities have discretion to meet other needs (LaingBuisson, 2016). As it is housing provision, care and support costs and housing costs are funded separately (LaingBuisson, 2016). Care and support costs are covered by regulations introduced by the Act, which specified that the same charging arrangements apply in all settings outside care homes (Department of Health, 2014). Housing and welfare benefits are available to fund housing costs for tenants (renters), while for purchasers there are various forms of leasehold arrangements. Extra care housing in England is not subject to direct regulation, but the provision of personal care, which must be separate from the accommodation, is regulated by the Care Quality Commission (2015).

Local authorities have seen extra care housing as a means to support people outside residential care, promote personalised care and maximise people's independence in a more enabling and homely alternative (Fletcher et al., 1999; Department of Health, 2005, 2014), while reducing costs (Kent County Council, 2016; Bristol City Council, 2018). The 1997-2010 UK government supported the development of specialist housing within joint strategies for housing and community care (Department of Health and Department of the Environment, 1997). In 2002, plans were announced for an expansion in provision (Department of Health, 2002), and the Extra Care Housing Fund was created to develop innovative housing with care arrangements (Department of Health, 2003b). Although extra care housing has been viewed as an alternative to care homes, care homes are still needed for residents requiring high levels of nursing care or continuous monitoring (LaingBuisson, 2016).

In 2003, there were around 21,000 extra care dwellings in England (Department of Health, 2003a) and, although supply has increased steadily, extra care housing offers much less accommodation than in care homes or sheltered housing. For the UK, 74,677 housing with care and 523,207 housing with support apartments were identified in 2017 (Housing Learning and Improvement Network, 2017); while there were 454,858 care home beds in December 2016 (Competition and Markets Authority, 2017). 
By providing a housing model of tenure, housing with care offers an alternative to residential care with security of tenure, while leasehold arrangements enable owneroccupiers to protect their housing equity. However, although 76 per cent of households containing someone aged 55 or over lived in an owner-occupied property in 2014-15 (Department for Communities and Local Government, 2016), 68 per cent of housing with care and 74 per cent of housing with support was rented in 2016 (LaingBuisson, 2016). Most leasehold retirement housing is managed by private, for-profit providers, although housing associations are increasingly offering low cost shared ownership and mixed tenure arrangements, and there is also a small but growing private sector rental market (LaingBuisson, 2016).

The Housing Learning and Improvement Network (2017) projected a shortfall of nearly 400,000 units of purpose-built housing by 2035, including nearly 160,000 units of housing with care and 231,000 units of sheltered housing, although the geographical base was not stated. Owner-occupier leasehold properties accounted for just under half (46 per cent) of the projected shortfall in housing with care, but for almost all of the projected shortfall in sheltered housing.

\section{Reviews of integrated housing with care}

Atkinson et al. (2014) identified three main themes in their review: the provision of care and support; the role of the built environment; and resident well-being. A recurrent theme relating to care and support was the ability of housing with care to accommodate residents across the spectrum of care needs, including the support of people with dementia. Despite the importance of the provision of care, the review found limited information on the delivery of care and support, and identified a range of ways in which 24-hour care was provided. It also found that some extra care schemes did not include communal dining areas. A number of studies examined the role of design, including the connection with the wider community. Studies of resident well-being identified the generally high level of satisfaction reported by residents. However, some studies had highlighted limitations, including problems with the support of people in the more advanced stages of dementia, social isolation of the frailest residents, issues relating to the greater levels of support for women than men, and tensions between people of different socio-economic backgrounds.

In relation to government policy, Atkinson et al. suggested that housing with care could support the management of the financial pressures created by a growing population of older people, and provide more financially viable alternatives to traditional models of care; and maximise quality of life by enabling people to have greater choice and control over their housing and care options. However, despite the belief among local authorities concerning the relative costs of housing with care, there was little peer-reviewed literature on costs.

The review by Atkinson et al. reinforced the findings of Croucher et al. (2006). Croucher et al. identified several gaps in the UK evidence base: the role of housing with care in supporting people from different ethnic groups; evidence on the quality of life; the role of telecare and assistive technologies; gender roles and relationships in feminised environments; end-of-life care; the support of people with different levels of frailty; and the circumstances in which people may move to different forms of provision. They also identified the importance of social support, social networks and activities on health and well-being, particularly in retirement communities, but also that the frailest people could 
be socially isolated. In addition to cost-effectiveness, Croucher et al. reported that the very limited evidence available seemed to indicate that it was more expensive than residential care, but possibly cheaper than home care.

Evans (2009a) described a number of developments designed to meet the needs of particular ethnic groups, but noted that there was little ethnic diversity within schemes. Overall, few residents in general extra care schemes come from ethnic minorities (Darton et al., 2012).

Darton and Muncer (2005) identified gaps in knowledge relating to information on provision, costs and outcomes, the characteristics of residents and staffing. In particular, comparative information was needed about extra care housing and care homes, including information on costs and the characteristics of residents. Also, there had been changes in the roles of scheme managers, with some providers separating the housing and care functions, partly due to legislative requirements relating to domiciliary care and care homes. However, this raised questions about whether a seamless service could be achieved when the functions were separated (Oldman, 2000). Darton and Muncer also identified the need to consider the range of types of extra care housing and to place it in the context of housing policies more generally, including developments to improve future proofing of housing environments.

The following section discusses key findings from recent studies relating to policy and practice issues identified in the reviews, focusing on resident characteristics, support for people with dementia, and costs and outcomes.

\section{Recent research}

\section{Resident characteristics and balance of care}

A number of studies have compared the characteristics of older people living in extra care housing with those of care home residents (Netten et al., 2011; Darton et al., 2012), or with those of people living in mainstream housing in the community (Kingston et al., 2001; Bernard et al., 2007; Holland et al., 2015, 2017), or with both (Callaghan and Towers, 2014; Phillips et al., 2015). Overall, the PSSRU evaluation found that people who moved into extra care were younger and much less physically and cognitively impaired than those who moved into care homes, although several schemes had a significant minority of residents with high levels of physical dependency (Darton et al., 2012). In the ASSET study, residents in extra care housing were, on average, less dependent, both physically and cognitively, than those living in care homes, although a minority of residents had similar levels of dependency to those in care homes (NIHR School for Social Care Research, undated). However, in the ECHO study there was some reported increase in the care needs of residents moving into extra care housing, in line with a change in the eligibility criteria used in the nomination of residents supported by one of the participating local authorities (NIHR School for Social Care Research, 2018).

A 'balanced population' was seen as necessary for tenants of sheltered housing to provide mutual support and to reduce demands on the warden (Butler et al., 1983), and extra care providers often aim for a balance of care needs among residents, such as onethird each with high, medium and low needs (Wright et al., 2010). However, local authorities have increased social care eligibility criteria and providers have been expected to support more residents with higher care needs (Murphy and Miller, 2008; Smith et al., 
2017). In the ECHO study, increased pressures on care workers and commissioning systems focused on completing specific care tasks reduced their ability to respond flexibly to residents' increasing care needs (Cameron et al., 2020b). Also, changes in the balance of care needs can affect relationships between residents (Croucher et al., 2007; Callaghan et al., 2009; Evans, 2009b; West et al., 2017).

\section{Dementia}

In the PSSRU study, levels of severe cognitive impairment were much lower in all the extra care schemes than for residents of care homes, even among schemes designed specifically to support residents with dementia (Darton et al., 2012). However, in the context of increasing levels of dementia among the population, and policy and personal preferences for enabling people to remain in their own homes, extra care housing is being seen as offering a model for supporting people with dementia, and innovations in extra care housing design have been made for this (Evans et al., 2020). Recent research has examined the relative roles of specialist and generic extra care housing. It may be easier to provide more dementia-friendly design in specialist schemes, but this would appear to be at the cost of promoting independence (Evans et al., 2020).

Various studies have suggested that extra care housing schemes can accept people in the early stages of the disease and support people who develop dementia while they are residents (Fletcher et al., 1999; Department of Health, 2003b; Vallelly et al., 2006; Croucher et al., 2007). However, integration is unpopular with residents living without dementia (O'Malley and Croucher, 2005), and residents living with dementia in generic schemes may be at risk of social exclusion due to the attitudes of other residents (Evans et al., 2020).

\section{Evidence on costs and outcomes}

A study of the costs before and after moving into one scheme in the PSSRU evaluation found that the overall cost per person increased, but this was associated with improved social care outcomes and improvements in quality of life (Bäumker et al., 2010). For the overall evaluation, the accommodation, living and social care costs were slightly lower than for a matched group of care home residents (Bäumker et al., 2011). Using a similar matching procedure, social care outcomes for residents living in extra care housing in the ASSET study were significantly higher than for people living in the community with similar levels of care need (Darton et al., in preparation).

In a longitudinal study of almost 4,000 residents in extra care housing, Kneale (2011) found that about one quarter experienced a reduction in care needs. Compared with a matched group of people living in the community, there were fewer admissions to hospital and fewer falls, and residents in extra care were also less likely to move to institutional care. In the light of these findings, Kneale suggested that moving into extra care housing could achieve a range of cost savings, with consequent benefits to quality of life.

In another longitudinal study of residents in 14 extra care villages and schemes operated by a single provider, Holland et al. (2015) found significant reductions in NHS costs, including in the duration of unplanned hospital stays, and significant reductions in the costs of providing the equivalent level of social care to that provided in the wider community. 


\section{Discussion}

In the UK, and internationally, a wide range of specialist housing has been developed to cater for people whose home is no longer suitable. Extra care housing provides a range of models of housing with care that appeal to individuals seeking social and leisure activities combined with personal care and support, either to meet existing or potential future needs. However, demand for specialist housing greatly exceeds supply, and the shortfall is projected to increase over time, both for rented and leasehold (owner-occupied) accommodation. Furthermore, the diverse range of specialist housing is confusing for older people and professionals alike, and much greater clarity is needed about what is being provided (House of Commons Communities and Local Government Committee, 2018).

Local authorities have seen extra care housing as a means to support people outside residential care, while reducing costs. Comparisons with residents living in residential care or in mainstream housing indicate that extra care housing can provide improved social care outcomes and a reduction in care needs, with potential cost savings and benefits to quality of life. However, funding restrictions and changes in eligibility criteria are placing pressure on the model of care, with more task-focused interactions with residents. Changes in eligibility criteria also affect the balance of care, which can create tensions between residents with different levels of need.

While the design of extra care housing appears to meet the needs of less dependent residents, those with physical or cognitive impairment can experience restrictions due to poor building design, leading to problems of social isolation (Callaghan et al., 2009; Barnes et al., 2012; Orrell et al., 2013). It may be easier to provide more dementia-friendly design in specialist schemes, although at the cost of promoting independence (Evans et al., 2020). In order to cater for increasing levels of frailty, particularly for residents living with dementia, buildings need to be designed with facilities located closely together (Evans et al., 2017, 2020). For example, restaurants are important in helping residents to develop friendships, and lunchtime may be the main time when they meet other people (Callaghan et al., 2009). However, communal facilities can account for up to 40 per cent of the floor area (LaingBuisson, 2016), and the service charges required can be beyond the means of residents with modest incomes and local authority funders. Following the economic downturn after 2009, the All Party Parliamentary Group on Housing and Care for Older People (2012) recommended that any reductions should be in communal facilities rather than in the quality of individual apartments, with more use made of neighbouring amenities, as in some other European provision (Homes and Communities Agency, 2009). However, this would adversely affect residents with higher levels of need. Residents with lower levels of need are more likely to be self-funded occupants of leasehold accommodation, and developers are likely to view larger-scale retirement villages offering 'lifestyle' facilities to such residents as a more attractive proposition (Smith et al., 2017).

Extra care housing schemes may be able to support their communal facilities by operating as community hubs, opening their facilities to the wider community. Although there can be tensions between residents and visitors (Callaghan et al., 2009), sharing facilities can increase cost-effectiveness, provide activities for scheme and local residents and reduce social isolation, and encourage preventative approaches to health and wellbeing, as well as advertising the scheme to potential new residents (Evans et al., 2017). However, the aims and philosophy of the scheme, and what to expect on moving 
in, must be made clear to prospective residents, particularly if the scheme caters for a range of needs, or provides facilities to the wider community (Croucher et al., 2006; Callaghan et al., 2009).

The COVID-19 pandemic has disproportionately affected people in the most vulnerable circumstances (ADASS, 2020a). Social distancing measures have restricted the use of communal areas and group activities in supported living environments (Housing Learning and Improvement Network, 2020). The design of extra care housing and retirement villages has generally helped to ensure a safe environment for residents, albeit at the cost of social interaction, and additional work for staff (Dutton, 2021). However, the pandemic appears to have adversely affected demand for communal provision, and it has been severely damaging financially for providers (ADASS, 2020a; Dutton, 2021). Understanding the impact of the pandemic on people's choices will be essential for future planning (Social Care Institute for Excellence, 2021).

Despite housing quality being central to health and well-being (House of Commons Communities and Local Government Committee, 2018; ADASS, 2020b; Social Care Institute for Excellence, 2021), there have been few instances of housing being aligned with health and social care (Bligh et al., 2015). There is very little reference to housing in the Care Act or, most recently, in the White Paper Integration and Innovation (Department of Health and Social Care, 2021). The government's plan for social care has been delayed repeatedly, but it will need to ensure that investment is made in housing that facilitates care and support and connects social care to wider changes in housing and infrastructure (Social Care Institute for Excellence, 2021). In particular, further investment in provision and more understanding of how to balance the expectations of residents with different needs will be necessary to support increasing levels of physical and cognitive frailty. Otherwise, extra care housing may become unviable for residents receiving publiclyfunded social care (Cameron et al., 2020a).

Research studies have identified the potential benefits and challenges of providing specialist housing, although a number of issues require further research - for example, supporting people with dementia and the needs of people in ethnic and other minority groups. However, research has concentrated on detailed, in-depth examinations of individual developments or relatively small numbers of schemes (Darton et al., 2012). Longitudinal studies have faced particular problems of drop-outs and changes over time (Netten et al., 2011; Holland et al., 2015; Cameron et al., 2019). The wide range of models of provision makes it particularly difficult to conduct larger-scale studies. However, policy on the alignment of housing with other forms of provision needs to be supported by costbenefit analyses (Social Care Institute for Excellence, 2021), and this remains a major gap in research.

\section{Acknowledgements}

This study was funded by the National Institute for Health Research (NIHR) Policy Research Programme (reference 103/0001). It draws on previously published material from research funded by the former Department of Health and the NIHR School for Social Care Research (NIHR SSCR). The views expressed are those of the author and not necessarily those of the NIHR, the NIHR SSCR or the Department of Health and Social Care. 


\section{References}

All Party Parliamentary Group on Housing and Care for Older People (2012) Housing our Ageing Population: Plan for Implementation (HAPPI2), http://www.housinglin.org.uk/APPGInquiry_HAPPI [accessed 27.11.2012].

Association of Directors of Adult Social Services (ADASS) (2020a) ADASS Coronavirus Survey, London: Association of Directors of Adult Social Services.

Association of Directors of Adult Social Services (ADASS) (2020b) Adult Social Care - Shaping a Better Future. Nine Statements to Help Shape Adult Social Care Reform, London: Association of Directors of Adult Social Services.

Atkinson, T. J., Evans, S., Darton, R., Cameron, A., Porteus, J. and Smith, R. (2014) 'Creating the asset base a review of literature and policy on housing with care', Housing, Care and Support, 17, 1, 16-25.

Barnes, S., Torrington, J., Darton, R., Holder, J., Lewis, A., McKee, K., Netten, A. and Orrell, A. (2012) ‘Does the design of extra-care housing meet the needs of the residents? A focus group study', Ageing and Society, 32, 7, 1193-1214.

Bäumker, T., Netten, A. and Darton, R. (2010) 'Costs and outcomes of an extra care housing scheme in England', Journal of Housing for the Elderly, 24, 2, 151-70.

Bäumker, T., Netten, A., Darton, R. and Callaghan, L. (2011) 'Evaluating extra care housing for older people in England: a comparative cost and outcome analysis with residential care', Journal of Service Science and Management, 4, 4, 523-39.

Bernard, M., Bartlam, B., Sim, J. and Biggs, S. (2007) 'Housing and care for older people: life in an English purpose-built retirement village', Ageing and Society, 27, 4, 555-78.

Bligh, J., Cairncross, L. and Porteus, J. (2015) Housing and Adult Social Care, Scoping Review, London: NIHR School for Social Care Research.

Bristol City Council (2018) 'Working with us for Better Lives': Market Position Statement for the Provision of Care and Support for Adults in Bristol, Bristol: Bristol City Council.

Butler, A., Oldman, C. and Greve, J. (1983) Sheltered Housing for the Elderly: Policy, Practice and the Consumer, London: George Allen and Unwin.

Callaghan, L., Netten, A. and Darton, R. (2009) The Development of Social Well-Being in New Extra Care Housing Schemes, York: Joseph Rowntree Foundation.

Callaghan, L. and Towers, A. (2014) 'Feeling in control: comparing older people's experiences in different care settings', Ageing and Society, 34, 8, 1427-51.

Cameron, A., Johnson, E. K. and Evans, S. (2020a) 'Older people's perspectives on living in integrated housing and care settings: the case of extra care housing', Journal of Integrated Care, 28, 3, 281-90.

Cameron, A., Johnson, E. K., Evans, S., Lloyd, L., Darton, R., Smith, R., Porteus, J. and Atkinson, T. (2020b) "You have got to stick to your times': care workers and managers' experiences of working in extra care housing', Health and Social Care in the Community, 28, 2, 396-403.

Cameron, A., Johnson, E. K., Lloyd, L., Evans, S., Smith, R., Porteus, J., Darton, R. and Atkinson, T. (2019) 'Using longitudinal qualitative research to explore extra care housing', International Journal of Qualitative Studies on Health and Well-being, 14, 1, 1-10.

Care Act 2014 (c. 23), Norwich: HMSO (TSO).

Care Quality Commission (2015) Housing with Care. Guidance on Regulated Activities for Providers of Supported Living and Extra Care Housing, October 2015, Newcastle upon Tyne: Care Quality Commission.

Competition and Markets Authority (2017) Care Homes Market Study. Final Report, London: Competition and Markets Authority.

Croucher, K., Hicks, L., Bevan, M. and Sanderson, D. (2007) Comparative Evaluation of Models of Housing with Care for Later Life, York: Joseph Rowntree Foundation.

Croucher, K., Hicks, L. and Jackson, K. (2006) Housing with Care for Later Life: A Literature Review, York: Joseph Rowntree Foundation. 
Darton, R., Bäumker, T., Callaghan, L., Holder, J., Netten, A. and Towers, A. (2012) 'The characteristics of residents in extra care housing and care homes in England', Health and Social Care in the Community, 20, 1, 87-96.

Darton, R. and Muncer, A. (2005) 'Alternative housing and care arrangements: the evidence', in B. Roe and R. Beech (eds.), Intermediate and Continuing Care, Oxford: Blackwell, 183-203.

Darton, R., Netten, A., Bäumker, T., Evans, S. C., Atkinson, T., Gardiner, C., Smith, R. and Cameron, A. (in preparation) 'Quality of life outcomes of extra care housing for older people in England'.

Department for Communities and Local Government (2016) English Housing Survey. Housing for Older People Report, 2014-15, London: Department for Communities and Local Government.

Department for Communities and Local Government (2017a) 50 Years of the English Housing Survey, London: Department for Communities and Local Government.

Department for Communities and Local Government (2017b) Fixing Our Broken Housing Market (Cm 9352), London: Department for Communities and Local Government.

Department for Communities and Local Government, Department of Health and Department for Work and Pensions (2008) Lifetime Homes, Lifetime Neighbourhoods. A National Strategy for Housing in an Ageing Society, London: Department for Communities and Local Government.

Department of Health (2002) 'Expanded services and increased choices for older people: investment and reform for older people's social services', Press Release 2002/0324, London: Department of Health.

Department of Health (2003a) Extra Care Housing Directory, Change Agent Team, Housing Learning and Improvement Network, and Elderly Accommodation Counsel, London: Department of Health.

Department of Health (2003b) Extra Care Housing for Older People: An Introduction for Commissioners, London: Department of Health.

Department of Health (2005) Independence, Well-being and Choice. Our Vision for the Future of Social Care for Adults In England (Cm 6499), Norwich: HMSO (TSO).

Department of Health (2014) Care and Support Statutory Guidance, Issued under the Care Act 2014, October 2014, London: Department of Health.

Department of Health and Department of the Environment (1997) Housing and Community Care: Establishing a Strategic Framework, London: Department of Health.

Department of Health and Social Care (2021) Integration and Innovation: Working Together to Improve Health and Social Care for All, The Department of Health and Social Care's legislative proposals for a Health and Care Bill (CP 381), London: Department of Health and Social Care.

Department of Health and Social Security, Scottish Office, Welsh Office and Northern Ireland Office (1981) Growing Older (Cmnd 8173), London: HMSO.

Dutton, R. (2021) Retirement Village and Extra Care Housing in England: Operators' Experience during the COVID-19 Pandemic, RE-COV Study Full Report, April 2021, Bristol: St Monica Trust.

Evans, S. (2009a) Community and Ageing: Maintaining Quality of Life in Housing with Care Settings, Bristol: Policy Press.

Evans, S. (2009b) "That lot up there and us down here': social interaction and a sense of community in a mixed tenure UK retirement village', Ageing and Society, 29, 2, 199-216.

Evans, S. C., Atkinson, T., Cameron, A., Johnson, E. K., Smith, R., Darton, R., Porteus, J. and Lloyd, L. (2020) 'Can extra care housing support the changing needs of older people living with dementia?', Dementia, 19, 5, 1492-1508.

Evans, S., Atkinson, T., Darton, R., Cameron, A., Netten, A., Smith, R. and Porteus, J. (2017) 'A community hub approach to older people's housing', Quality in Ageing and Older Adults, 18, 1, 20-32.

Fletcher, P., Riseborough, M., Humphries, J., Jenkins, C. and Whittingham, P. (1999) Citizenship and Services in Older Age: The Strategic Role of Very Sheltered Housing, Beaconsfield: Housing 21.

Holland, C., Boukouvalas, A., Wallis, S., Clarkesmith, D., Cooke, R., Liddell, L. and Kay, A. (2017) 'Transition from community dwelling to retirement village in older adults: cognitive functioning and psychological health outcomes', Ageing and Society, 37, 7, 1499-1526. 
Holland, C., Carter, M., Cooke, R., Leask, G., Powell, R., Shaw, R., West, K., Clarkesmith, D., Collins, J., Hagger, B., Kay, A., Lambie, J., Liddell, L., Wallis, S. and Boukouvalas, A. (2015) Collaborative Research between Aston Research Centre for Healthy Ageing (ARCHA) and the ExtraCare Charitable Trust. The Final Report, Birmingham: Aston University.

Homes and Communities Agency (2009) HAPPI. Housing our Ageing Population: Panel for Innovation, London: Homes and Communities Agency.

House of Commons Communities and Local Government Committee (2018) Housing for Older People (HC 370, 2017-19), London: House of Commons.

Housing Learning and Improvement Network (2017) Written Evidence Submitted by the Housing Learning and Improvement Network [HOP 012], London: Housing Learning and Improvement Network.

Housing Learning and Improvement Network (2020) Coronavirus (COVID-19) - Housing and Care in Specialist Housing, A Housing LIN Practice Briefing (No1), 13 October 2020, 7th edn, London: Housing Learning and Improvement Network.

Howe, A. L., Jones, A. E. and Tilse, C. (2013) 'What's in a name? Similarities and differences in international terms and meanings for older peoples' housing with services', Ageing and Society, 33, 4, 547-78.

Kent County Council (2016) Social Care, Health and Wellbeing - Community Support Market Position Statement, Maidstone: Kent County Council.

Kingston, P., Bernard, M., Biggs, S. and Nettleton, H. (2001) 'Assessing the health impact of age-specific housing', Health and Social Care in the Community, 9, 4, 228-34.

Kneale, D. (2011) Establishing the Extra in Extra Care: Perspectives from Three Extra Care Housing Providers, London: International Longevity Centre - UK.

LaingBuisson (2016) Extra Care and Retirement Communities UK Market Report, 14th edn, London: LaingBuisson.

Ministry of Housing, Communities and Local Government (2020) English Housing Survey. Headline Report, 2019-20, London: Ministry of Housing, Communities and Local Government.

Ministry of Housing, Communities and Local Government (undated) English Housing Survey 2018-19. Accessibility of English Homes, https://www.gov.uk/government/statistics/english-housing-survey2018-accessibility-of-english-homes-fact-sheet [accessed 14.07.2020].

Murphy, W. and Miller, L. (2008) Nomination Arrangements in Extra Care Housing, Housing LIN Factsheet No. 25, London: Housing Learning and Improvement Network, Care Services Improvement Partnership, Department of Health.

Netten, A., Darton, R., Bäumker, T. and Callaghan, L. (2011) Improving Housing with Care Choices for Older People: An Evaluation of Extra Care Housing, Canterbury: Personal Social Services Research Unit, University of Kent.

NIHR School for Social Care Research (2018) Provision of Social Care in Extra Care Housing: The ECHO Study, Research Findings 73, London: NIHR School for Social Care Research, https://www.sscr.nihr. ac.uk/wp-content/uploads/SSCR-research-findings_RF073.pdf [accessed 25.02.2021].

NIHR School for Social Care Research (undated) Adult Social Care Environments and Settings, Research Findings 34, London: NIHR School for Social Care Research, https://www.sscr.nihr.ac.uk/wp-content/ uploads/SSCR-research-findings_RF034.pdf [accessed 25.02.2021].

O'Malley, L. and Croucher, K. (2005) 'Housing and dementia care - a scoping review of the literature', Health and Social Care in the Community, 13, 6, 570-77.

Office for National Statistics (2013) What Does the 2011 Census Tell Us about Older People, Newport: Office for National Statistics.

Office for National Statistics (2015) 2011 Census Analysis: What Does the 2011 Census Tell Us about People Living in Communal Establishments, Newport: Office for National Statistics.

Oldman, C. (2000) Blurring the Boundaries: A Fresh Look at Housing and Care Provision for Older People, Brighton: Pavilion Publishing.

Orrell, A., McKee, K., Torrington, J., Barnes, S., Darton, R., Netten, A. and Lewis, A. (2013) 'The relationship between building design and residents' quality of life in extra care housing schemes', Health and Place, 21, 52-64. 
Phillips, J. E., Dobbs, C., Burholt, V. and Marston, H. (2015) 'Extracare: does it promote resident satisfaction compared to residential and home care?', British Journal of Social Work, 45, 3, 949-67.

Reed, C. A., Faulkner, G. J. and Bessell, R. (1980) Your Own Front Door: A Study of Very Sheltered Housing in Warwickshire, 1979-80, Warwick: Warwickshire County Council Social Services Department.

Smith, R., Darton, R., Cameron, A., Johnson, E. K., Lloyd, L., Evans, S., Atkinson, T. J. and Porteus, J. (2017) 'Outcomes-based commissioning for social care in extra care housing: is there a future?', Housing, Care and Support, 20, 2, 60-70.

Social Care Institute for Excellence (2021) Future Options for Housing and Care: Improving Housing that Facilitates Care and Support for Older People, Commission on the Role of Housing in the Future of Care and Support - Policy discussion paper, London: Social Care Institute for Excellence.

Vallelly, S., Evans, S., Fear, T. and Means, R. (2006) Opening Doors to Independence - A Longitudinal Study Exploring the Contribution of Extra Care Housing to the Care and Support of Older People with Dementia, London: Housing 21.

West, K., Shaw, R., Haggar, B. and Holland, C. (2017) 'Enjoying the third age! Discourse, identity and liminality in extra-care communities', Ageing and Society, 37, 9, 1874-97.

World Health Organization (2015) World Report on Ageing and Health, Geneva: World Health Organization.

Wright, F., Tinker, A., Mayagoitia, R., Hanson, J., Wojgani, H. and Holmans, A. (2010) 'What is the 'extra' in extra care housing?', British Journal of Social Work, 40, 7, 2239-54. 